Int. J. Dev. Biol. 59: 33-39 (2015)

doi: $10.1387 / \mathrm{ijdb} .150047 \mathrm{dd}$

\title{
Apaf1 in embryonic development - shaping life by death, and more
}

\author{
DANIELA DE ZIO*,1,2, EMILIANO MAIANI ${ }^{1}$ and FRANCESCO CECCONI*,1,2 \\ ${ }^{1}$ Cell Stress and Survival Unit, Danish Cancer Society Research Center, Copenhagen, Denmark and \\ IIRCCS Fondazione Santa Lucia, and Department of Biology - University of Rome Tor Vergata, Rome, Italy
}

\begin{abstract}
Apaf1 has been studied hitherto for its key role in regulating the formation of the apoptotic core machinery, the apoptosome, to induce programmed cell death. Apaf1 involvement in orchestrating this process during embryonic development has been widely documented and constitutes a breakthrough in developmental biology. In this review, we aim to highlight the origin of Apaf1 discoveries and how findings, mainly based on the analysis of knock-out mouse models, have led us to consider Apaf1 as a master player in fine-tuning apoptosis during embryonic development. Likewise, we also attempt to establish how Apaf1 function is locally time-dependent in regulating neurodevelopment and becomes dispensable during neuron maturation. We go on to discuss Apaf1's new functions which have been unveiled in recent years and which could revise or, at least, adjust the common view of Apaf1 having merely an apoptotic role. Hence, by presenting clear indications on the pro-survival roles of Apaf1, this review seeks to provide novel and more complex insights into Apaf1 involvement in nervous system development.
\end{abstract}

KEY WORDS: apoptosis, neurodevelopment, centrosome

\section{Apaf1 during development: the origin}

Apoptosis is a programmed cell death (PCD) process deputed to remove non-necessary cells, in order to maintain tissue homeostasis. Although it extensively occurs during the entire life of the organism, apoptosis is also deemed a fundamental process to guarantee a correct embryonic development.

There are two major routes of apoptosis: the extrinsic pathway of apoptosis, mediated by tumor necrosis factor (TNF)-family death receptors, and the intrinsic pathway of apoptosis, mediated by the mitochondrial release of cytochrome $c$ and dependent on the balance between pro- and anti-apoptotic Bcl2 family members (Galluzzi etal., 2012). Among the main factors regulating apoptosis, the Apoptotic protease activating factor1 (Apaf1) is the key molecule of the core apoptotic machinery, as it is involved in forming the apoptosome, a ring-like platform deputed to activate effector Caspase-3, -6 or -7 to execute cell death (Bratton and Salvesen, 2010, Yuan and Akey, 2013, Yuan et al., 2013). More particularly, the apoptosome is composed of seven Apaf1 molecules that, together with cytochrome $c$ (released from mitochondria) and adenine nucleotides (ATP/ dATP), form a large complex interacting with pro-Caspase-9, this being eventually proteolyzed and activated [reviewed in (Bratton and Salvesen, 2010)].

Apaf1 ortholog Ced4 had been initially characterized in the nematode Caenorhabditis elegans (C. elegans) as the molecule able to oligomerize into a tetrameric apoptosome, to activate the Caspase-9 ortholog Ced3, and to induce cell death (Horvitz, 1999, Yan et al., 2005) during worm development. 131 of the total 1090 cells of $C$. elegans were found to be completely removed by PCD via a Ced4/Ced3-mediated pathway, their elimination having been demonstrated as fundamental to a correct worm development

Abbreviations used in this paper: ANR, anterior neural ridge; Apaf1, Apoptotic protease activating factor 1; Bcl2, B-cell lymphoma 2; Ced3, Caenorhabditis Elegans Death 3; Ced4, Caenorhabditis Elegans Death 4; Ced9, Caenorhabditis Elegans Death 9; Chk1, checkpoint kinase-1; DDR, DNA damage response; DSB, double strand break; E16.5, embryonic stage 16.5; Egll, egg laying abnormal-1; ETNA, embryonic telencephalic naïve Apaf1; Fgf8, Fibroblast growth factor 8; FNP, frontonasal prominence; Fog, forebrain overgrowth; HR, homologous recombination; miR-29b,; microRNA-29b; NBS, Nijmegen breakage syndrome protein; NHEJ, nonhomologous end-joining; NPGs, Neural progenitor cells; OSNs, olfactory sensory neurons; PARC, Parkin-like cytoplasmic protein; PCD, programmed cell death; Shh, Sonic hedgehog; TNF, tumor necrosis factor; $\gamma$-TuSC, small $\gamma$-tubulin complex; XRCC2, X-ray repair cross-complementing protein 2; XRCC4, X-ray repair cross-complementing protein 4 .

\footnotetext{
Accepted: 6 May 2015.

ISSN: Online 1696-3547, Print 0214-6282

*Address correspondence to: Francesco Cecconi. Department of Biology, University of Rome "Tor Vergata", Via della Ricerca Scientifica, 00133 Rome, Italy.

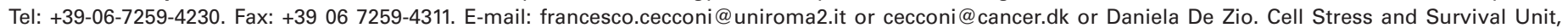

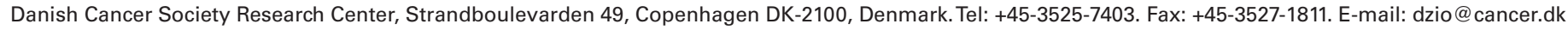


(Ellis and Horvitz, 1991, Ellis et al., 1991). In a series of elegant experiments performed by means of Ced3, Ced4, Ced9 (Bcl2 family ortholog) and Egl1 (BH3-only ortholog) gene mutants, Horvitz and colleagues foresaw the functional role of apoptosis during development and identified the activation cascade of these genes in the apoptotic pathway (Ellis and Horvitz, 1986, Ellis and Horvitz, 1991, Metzstein et al., 1998). This was a groundbreaking step in the detailed understanding of PCD's role in development, inspiring a host of publications in the last 20 years aimed at unveiling this process's function in higher organisms. The discovery of Apaf1 and the comprehension of its implication in PCD is a case in point.

This paper focuses on Apaf1's pivotal role during embryonic development as has been demonstrated to be in regulation of neuronal cell death; it then outlines how the more recently discovered multiple functions of Apaf1 might amplify its significance in guaranteeing a correct development.

\section{Mouse knock-out models}

In the late 1990s the role of mammalian Apaf1 in vivo began to be characterized thanks to the use of knock-out mouse models that came to the fore in that period. By means of gene trap and gene targeting approaches, two Apaf1 knock-out mice were generated in 1998 by different groups, both mice showing exceptionally similar phenotypes with embryonic or perinatal lethality, namely: $i$ ) brain overgrowth due to the hyperproliferation of neuronal cells; ii) neural tube defects (e.g. exencephaly and spina bifida); iii) severe craniofacial malformations; iv) persistence of interdigital webs or delay in their removal (Cecconi et al., 1998, Yoshida et al., 1998). These findings attributed to Apaf1 a key role in regulating histogenetic cell death, since its deficiency severely compromised the occurrence of apoptosis in affected areas, arguing for an Apaf1 role in the fine control of cell numbers in developing brain (Cecconi et al., 1998, Yoshida et al., 1998). Apaf1 was also demonstrated as being implicated in morphogenetic cell death, since it was involved in $\mathrm{PCD}$ required for the correct development of the neural tube, lens, skull, face, inner ear and limbs (Cecconi et al., 1998, Cecconi et al., 2004, Yoshida et al., 1998). Eventually, Apaf1 was also found out to be involved in the regulation of phylogenetic cell death, since Apaf1 ablation affected the elimination of the hyaloid artery system in the developing eye (Cecconi et al., 1998).

In the meantime, Caspase-3 and Caspase- 9 knock-out mice were also being generated, confirming a direct implication of these enzymes in the PCD of the nervous system (Hakem et al., 1998, Kuida et al., 1998, Kuida et al., 1996). They displayed a phenotype resembling Apaf1-/mice, albeit with a decreased neuronal apoptosis that resulted in neuro-developmental abnormalities, including expanded ventricular zone, ectopic and duplicated neuronal structures, and gross brain malformations (Hakem et al., 1998, Kuida et al., 1998, Kuida et al., 1996). This was a clear proof that Apaf1, Caspase- 9 and Caspase- 3 were all components of the same apoptotic pathway during brain development. Furthermore, knock-in mice expressing a mutant cytochrome $c$, which retained normal electron transfer functions but failed to activate Apaf1, showed embryonic or perinatal lethality caused by defects in brain development (Hao et al., 2005). Of note, all these mutants displayed expansions of the cortex and midbrain that produced cranial enlargement and, most importantly, resulted in a neurological phenotype similar to that seen in Apaf1 and Caspase 9, and, less severely, Caspase 3 null mice (Cecconi et al., 1998, Hakem et al., 1998, Hao et al., 2005, Kuida et al., 1998, Kuida et al., 1996, Yoshida et al., 1998). Therefore, by phenocopying these knock-outs, cytochrome $c$ knock-in mutant showed the direct implication of this molecule in the nervous system PCD, highlighting that the more upstream in the pathway the gene inactivated was, the more severe the phenotype which resulted. An emblematic example was the knock-out of Caspase-3 which displayed mild brain abnormalities and a longer lifespan compared to that of cytochrome c, Apaf1 and Caspase-9 mutants (Cecconi et al., 1998, Hakem et al., 1998, Hao et al., 2005, Kuan et al., 2000, Kuida et al., 1998, Kuida et al., 1996, Yoshida et al., 1998).

These differences among knock-out models suggested the existence of a compensatory effect plausibly mediated by other molecules. In agreement with this hypothesis, it was found that Caspase-7 function and basal expression defined the strainspecific brain phenotype of Caspase-3-null mice, which appeared to be resistant to Caspase-3 deficiency and developed normally if obtained in the C57BL16J (B6) strain. On the other hand, if Caspase-3knock-out was generated in a 129S1/SvImJ (129) strain, this
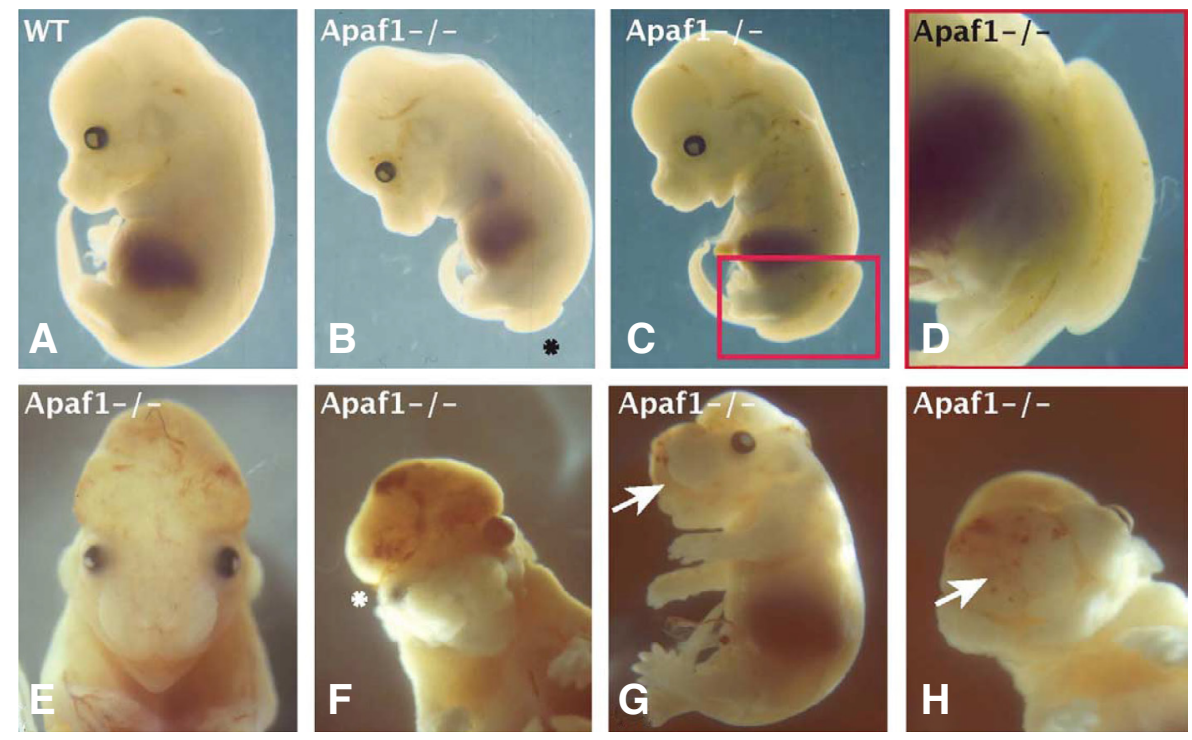

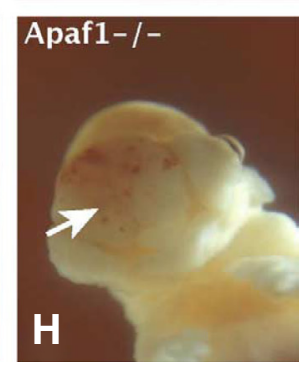

Fig. 1. The phenotype of the Apaf1 knock-out mouse. Excerpts from (De Zio et al., 2005). (B-H) Apaf1\% embryos (Cecconiet al., 1998) are displayed versus a wild-type (WT) counterpart (A). (B,C,D) Spina bifida, clearly evident at e14.5. The asterisk $\left.{ }^{*}\right)$ in $(B)$ indicates a milder phenotype if compared to the embryo in (C) (and its enlargement in D). Brain overgrowth (E,F) and craniofacial defects (arrows in $\mathbf{( G , H ) ; ~ l a t e r a l ~ a n d ~ f r o n t a l ~ v i e w ~ o f ~ t h e ~}$ same embryo, respectively) are detected at e15.5. The asterisk in (F) indicates eye abnormality. For all panels reprinted we acknowledge Elsevier: Seminars in Cell \& Developmental Biology, De Zio et al., 16, 281-294, copyright 2005. 
mouse displayed severe brain defects (Houde et al., 2004). Thus, a proper balance between the expression of different players in the apoptotic pathways, such as Caspase-7 and Caspase-3, could be critical in determining cell death during mouse development, and more specifically neurodevelopment.

\section{Apaf1 in neurodevelopment}

The development of the nervous system is the result of proliferation, differentiation, migration and selective cell death. Neural progenitor cells (NPCs) proliferate in the ventricular zone of the neural tube, giving rise to neurons and glia cells. Subsequently, post-mitotic neuroblasts start to differentiate and migrate to the external layers of the neural tube. The cyto-architecture of the mature nervous system is profoundly determined by apoptosis. Indeed, the delicate balance between proliferation and death of both NPCs and post-mitotic cells determines the size and shape of the nervous system. It is now commonly accepted that apoptosis occurs in both neuronal cell populations in order to control the final number of neurons and glia cells, keeping in growth only those able to establish functional synaptic connections with their targets [reviewed in (De Zio et al., 2005)].

Due to the considerable aberrant phenotype of $A$ paf $1 \%$ in the context of brain development, Apaf1 has widely been studied for its contribution to the regulation of apoptosis occurring both in NPCs and in post-mitotic neurons. As previously mentioned, the disruption of the pro-apoptotic gene Apaf1 in the developing nervous system results in the uncontrolled number of neuronal cells and in the inhibition of morphogenetic cell death in the neural tube, which often leads to the generation of spina bifida (Fig. 1) (Cecconi et al., 1998, De Zio et al., 2005, Yoshida et al., 1998). Such a deep implication of Apaf1 in neurogenesis has also been documented by other mice mutants displaying a loss of Apaf1's functional apoptotic activity.

Apart from the fully knock-out models specifically targeting Apaf1, another mutant named forebrain overgrowth (fog) was discovered in 1997 (Harris et al., 1997) to carry a mutation mapping in the same chromosomal region of Apaf1, but without any associated gene being characterized. Surprisingly this mutation affected neural tube development with the phenotype including mono- or bi-lateral brain bumps alongside subcutaneous hemorrhage covered by hairbearing skin in adults. The fog mutant was not lethal; however, a number of animals did die around embryonic stage 16.5 (e16.5), occasionally displaying spina bifida that could be associated with a defective neural phenotype. Although fog mutation-associated gene has not yet been discovered, it was demonstrated that fog mutant displayed loss of Apaf1 activity and reduced protein expression due to an aberrant processing of Apaf1 transcript (Honarpour etal., 2001). Double heterozygous for Apaf1 and fog showed the same defects as Apaf1 or fog individual homozygous, strongly suggesting that fog could represent a hypomorphic allele of Apaf1 (Honarpour et al., 2001, Moreno et al., 2002). Apaf1 down-regulation also in this case led to the survival of neural progenitors resulting in aberrant brain development. Cerebral malformations in Apaf1 and fog double heterozygous telencephalon were, indeed, ascribed to the presence of an abnormally high number of cells.

Very recently, a new mutation, named yautja, has shown a defective embryonic development similar to that of the Apaf1/- mouse, namely, compressed forebrain, cranial and caudal neural tubes defects, craniofacial abnormalities, delayed removal of interdigital webs (Fig. 2) (Long et al., 2013). Yautja is a novel loss-of-function allele of Apaf1 harboring a Leu375Pro point mutation which produces Apaf1 at normal levels during embryonic development, although it represents a functionally-null protein (Long et al., 2013). In particular, Long and colleagues found significant morphological alterations in the yautja mutant due to a defective craniofacial development, including cleft maxilla and widened frontonasal prominence (FNP). A reduced rate of apoptosis in the developing nervous system, namely in the ventral forebrain region containing Sonic hedgehog (Shh)-expressing cells, has been indicated to bring about the persistent activation of Shh signaling pathway, this being widely involved in regulating organogenesis during embryonic development (Choudhry et al., 2014, Matise and Wang, 2011). This possibly led to increased cell proliferation in the FNP and, ultimately, to the yautja mutant's abnormal craniofacial phenotype.

Apaf1 has long been deemed a paradigmatic protein in neurodevelopmental apoptosis. However, in recent years conflicting results have emerged to demonstrate that the absence of Apaf1-mediated apoptosis was not the principal event triggering some of the neural defects so far described in Apaf1 knock-out, or its related mutants.
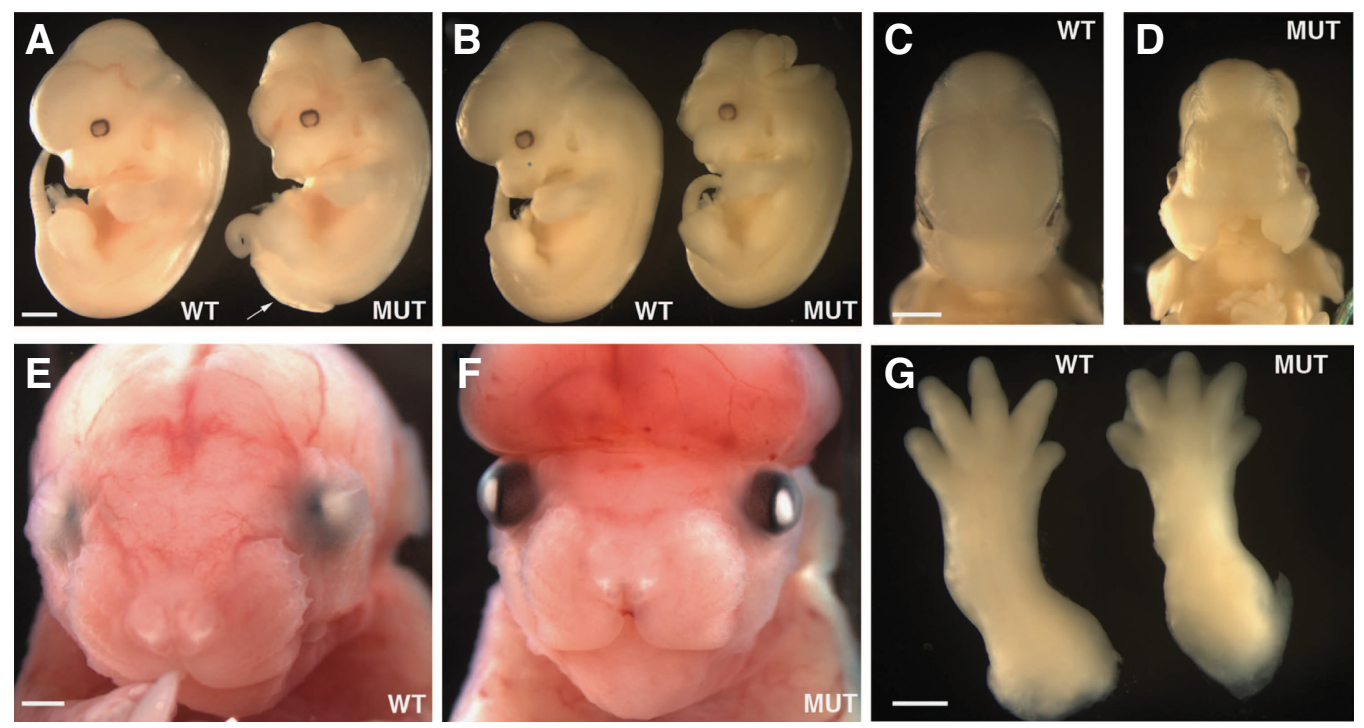

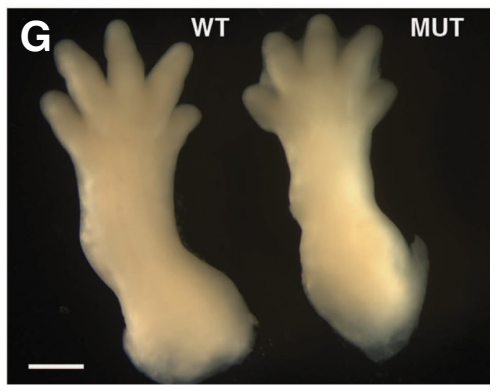

Fig. 2. The phenotype of the yautja mutant mouse. Excerpts from (Long et al., 2013). Wild-type (WT) and yautja mutants (MUT) at different embryonic stages are displayed: (A-D) e12.5; (E,F) e17.5; (G) e15.5. Defects in the closure of the cranial neural tube $(\mathbf{A}, \mathbf{B}, \mathbf{F})$ and caudal neural tube (A, arrow) are shown. Alterations in craniofacial development (D, F), eyelid closure (F) and interdigital web removal (G) are clearly detected. Scale bars, $1 \mathrm{~mm}$. All panels reprinted by permission from Nature Publishing Group: Cell Death \& Differentiation, Long et al., 20 (11), 1510-1520, copyright 2013. 
Specifically, Apaf1 or Caspase-3 mediated apoptosis at the site of fusion of the neural folds during the midbrain and hindbrain's neural tube closure was found not to be essential for completion of neural tube closure (Massa et al., 2009). Equally intriguing was the recent finding by Nonomura and colleagues showing that Apaf1 or Caspase-9-mediated apoptosis occurring specifically in the developing brain's anterior neural ridge (ANR) area was responsible for the regulation of brain development's early phases (Nonomura et al., 2013). Indeed, according to Nonomura and colleagues, initial causes of the brain abnormalities observed in Apaf1\% and Caspase-9-/ mice were due to insufficient brain ventricle expansion occurring at early developmental stages, these then leading to uncomplete closure of cranial neural tube (Nonomura et al., 2013). At a molecular level, apoptosis deficiency resulted in the persistence in ANR of non-proliferative cells, which usually disappear around e10.5, expressing the morphogen Fgf8. This caused a perturbation in the expression pattern of Fgf8 gene targets and led to an alteration in the underlying signalling pathways in the cells of ventral forebrain.

\section{Apaf1 in mature neurons}

Although Apaf1 is fundamental for the occurrence of cell death in NPCs, it has not been found to be necessary in developing post-mitotic neurons which are establishing synaptic connections (Oppenheim et al., 2008). Indeed, while in the presence of Apaf1, several populations of post-mitotic neurons in the central and peripheral nervous system die by apoptosis, they are still able to undergo cell death through a different, autophagy-related, mechanism in conditions of Apaf1 deficiency (Oppenheim et al., 2008). This is reasonable since, usually, Apaf1 expression levels dramatically decrease in mature neurons, in order to make them more resistant to stressful conditions throughout the lifetime (Wright et al., 2007). Other lines of evidence confirm this assumption. For instance, synaptic activity has been demonstrated to down-regulate the components of the intrinsic apoptotic pathway, namely Apaf1 and Caspase-9, again conferring resistance to diverse insults (Leveille et al., 2010). The induction of the small non-coding RNA miR-29b, deputed to selectively inhibit the pro-apoptotic BH3-only genes during neuronal maturation, is another example of how the cell can counteract PCD, since it is no longer beneficial for healthy neurons (Kole et al., 2011). In addition, it has been found very recently that post-mitotic neurons show an increased expression of the E3 ligase PARC which selectively targets mitochondriareleased cytochrome $c$ to degradation via the proteasome (Gama et al., 2014). By this means, mature neurons strategically prevent apoptosis under mitochondrial stress.

All this evidence confers on Apaf1 a more complex role in regulating PCD during neurodevelopment: It is effectively needed in fine-tuning apoptosis (locally and timing-dependent) during early neurodevelopment. By contrast, it becomes dispensable during neuron maturation.

\section{Alternative functions of Apaf1}

\section{Apaf1 and DNA damage}

Although the mostcharacterizedApaf1 function refers to caspase activation required for mitochondrial apoptosis, a non-apoptotic role for Apaf1 has been also described in responding to genotoxic stress (Mouhamad et al., 2007, Zermati et al., 2007). Following DNAdamage, cells orchestrate a series of events, comprehensively named 'DNA damage response' (DDR), aimed at safeguarding genomic stability (Bekker-Jensen and Mailand, 2010). The DDR involves: i) sensors, which recognize DNA lesions and initiate the signaling response, ii) transducers that amplify the damage signal, and iii) effectors, which branch the response into a series of downstream pathways. The activation of cell cycle checkpoints is a hallmark of the DDR and induces the block of the cell cycle in order to allow DNA lesion repair. In 2007, Zermati et al., showed that Apaf1 influenced cell cycle regulation upon DNA damage (Zermati et al., 2007). In particular, they demonstrated that Apaf1 ablation affected the S-phase arrest induced by sub-apoptotic doses of cisplatin. Indeed, Apaf1-silenced cells, treated with DNA damage inducers, did proceed to the cell cycle owing to a reduced activation of the checkpoint kinase Chk1. The absence of any correlation with apoptosis was elegantly demonstrated by the finding that ectopic expression of an Apaf1 mutant, which was no longer able to activate Caspase-9, still affected cell cycle progression (Zermati et al., 2007). Although the molecular mechanism(s) by which Apaf1 can modulate the cell cycle is/are still missing, further evidence has indicated that Apaf1 depletion sensitizes cells to chromosomal instability induced by different types of DNA damage, eventually validating a cell cycle-related function of Apaf1 in DDR (Mouhamad et al., 2007).

Notably, a series of indications suggest that DDR influences neurodevelopment. For this reason several mice models lacking proteins involved in DDR display neuronal defects [reviewed by (Barzilai et al., 2008, O'Driscoll and Jeggo, 2008)]. The double strand break (DSB) is considered the most dangerous DNA lesion, and eukaryotic cells possess two main mechanisms for its repair: the non-homologous end-joining (NHEJ) repair, an error-prone mechanism, and an error free process based on homologous recombination (HR) between sister chromatids. It has been shown that a defect in the NHEJ repair pathway, caused by the absence of X-ray repair cross-complementing protein 4 (XRCC4) or Ligase IV, resulted in embryonic lethality due to excessive apoptosis in the nervous system (Barnes et al., 1998, Gao et al., 1998). Furthermore, mutations of proteins involved in HR repair pathway (e.g. X-ray repair cross-complementing protein 2, Xrcc2, and Nijmegen breakage syndrome protein, NBS) cause proliferation/apoptosis defects in proliferating NPCs (Frappart et al., 2005, Orii et al., 2006). Given these data, it is possible to speculate that the DDRrelated function of Apaf1 is implicated in neurodevelopment. Indeed, studies on Apaf1/ embryos clearly provide indications about the effect of Apaf1-deficiency in cellular proliferation of neuronal cells (Cecconi et al., 1998, De Zio et al., 2005, Yoshida et al., 1998). Whether neural proliferating cells are or are not those escaping apoptosis, the function of Apaf1 related to cell cycle and DDR may however contribute to the proliferative phenotype. A further direct relation among Apaf1, DDR and neurodevelopment is provided by the evidence that Ku70/86, a key player in NHEJ repair, has been found to be involved in the repression of Apaf1 gene in embryonic NPCs (ETNA) upon DNA damage induction (De Zio et al., 2012, De Zio et al., 2011). In particular, Ku70/Ku86 inactivation results in aberrant neural apoptosis in many types of developing embryonic neurons from spinal cord, cerebral cortex, midbrain, and hindbrain (Gu et al., 2000). This suggests that a higher expression of Apaf1 in the nervous system caused by Ku70/86 absence might lead to a 
block of cell proliferation and an increase in apoptosis. Altogether, these findings define a higher complexity level by which Apaf1 can modulate the correct progression of neuronal development: i.e. by means of cell cycle control and apoptosis induction.

\section{Apaf1 and the centrosome}

In 2009, Apaf1 was also proven to interact with the centrosomal protein hepatocellular carcinoma antigen 66 (HCA66) required for the stability of the small $\gamma$-tubulin complex ( $\gamma$-TuSC) (Fant et al., 2009). $\gamma$-tubulin is one component of the pericentriolar material in the centrosome, promoting the nucleation of microtubule polymers from $\alpha-\beta$-tubulin dimers. The centrosome is the main microtubule-organizing center in the cell and is the classical site of microtubule nucleation and anchoring (Khodjakov and Rieder, 1999, Oegema et al., 1999). By virtue of this interaction, we decided to investigate Apaf1's possible role in the centrosome, and surprisingly descovered that Apaf1 was definitively involved in the regulation of centrosome morphology and function (Ferraro et al., 2011). In particular, Apaf1-deficient cells deriving from Apaf1 knock-out embryos (ETNA cells and mouse embryonic fibroblasts) showed centrosome defects associated with an impairment of centrosomal microtubule nucleation and cytoskeleton organization. The most important evidence emerging from this work was that the centrosome-related function of Apaf1 was carried out during cell life and was not related to its apoptotic role (Ferraro et al., 2011). We characterized an additional pro-survival role of Apaf1 within the processes regulated by the centrosome, such as spindle formation, mitosis, mitochondrial morphology and cell migration (Ferraro et al., 2011). Therefore, a potential role of Apaf1 in the processes involved in neurodevelopment based on this novel, non-apoptotic, centrosome-related function, could be also speculated. Indeed, the centrosome has been widely demonstrated as being one of the master regulators of neuronal differentiation and migration (Higginbotham and Gleeson, 2007, Kuijpers and Hoogenraad, 2011). A paradigm is the down-regulation of the centriolar satellite protein $\mathrm{PCM}-1$ in developing cortical neurons, which has been found to affect axon formation and neuronal migration (de Anda et al., 2010). Matching these observations, we have very recently demonstrated that Apaf1-deficient cortical neurons show impaired axonogenesis due to centrosome and Golgi alterations (De Zio et al., 2015). In addition, a number of centrosomal gene mutations bring about severe neurodevelopmental disorders, leading to various neuropsychiatric diseases (Higginbotham and Gleeson, 2007, Kuijpers and Hoogenraad, 2011).

In support of this hypothesis, it should be borne in mind that the Apaf1-dependent activity of caspases has recently been linked to the formation of a proper neural network during neurodevelopment, although this occurs without any induction of apoptosis. In particular, research has shown a direct implication of Apaf1 and Caspase- 9 in the development of the olfactory sensory neurons (OSNs), where the specific activation of caspases was required for the proper axonal projection, synapsis formation and complete neuron maturation (Ohsawa et al., 2010). This is another example supporting a more complex role for Apaf1 in neurodevelopment, which should not necessary involve apoptosis.

\section{Future perspectives}

All the evidence reported in this review indicates the depth of Apaf1's involvement in embryonic development, namely in the nervous system. However, based on a more general concept whereby the lack of Apaf1-mediated apoptosis is the principal cause leading to the aberrant neuronal phenotype, the common belief is now shifting to a more complex overview, taking into account the different roles played by Apaf1 and which do not necessarily deal with apoptosis (Fig. 3). Being able to investigate Apaf1 functions in time- and tissue-dependence remains an important challenge, opening up the possibility of unveiling the impact of Apaf1's nonapoptotic functions in embryonic development. This could lead to a more complete understanding of Apaf1 contribution to the development of each neural cell population during various phases of nervous system development.
Fig. 3. Proposed model of Apaf1-mediated regulation of neurodevelopment. Apaf1 can regulate neurodevelopment by inducing apoptosis through the activation of the multiprotein complex called apoptosome. Apaf1 is composed by different domains: a caspase recruitment domain (CARD), an ATPase domain (NB$A R C)$ and several WD40 repeat domains responsible for cytochrome c binding. Upon cytochrome c binding, Apaf1 oligomerizes and forms the apoptosome. The apoptosome binds and activates the initiator Caspase-9, activating the apoptotic process. Besides the apoptotic role of Apaf1, other Apaf1 functions can be relevant in neurodevelopment. Since it is involved in the regulation of centrosome morphology and function, Apaf1 could affect the centrosome-regulated processes of neuronal differentiation and migration. Moreover, Apaf1 is connected with the DNA damage response, thus dealing with cell proliferation control. Indeed, Apaf1 regulates cell cycle by affecting the activation of the checkpoint kinase-1 (Chk1) upon DNA damage. Through this cellcycle-related function, Apaf1 can contribute to regulate the correct progression of neuronal development.

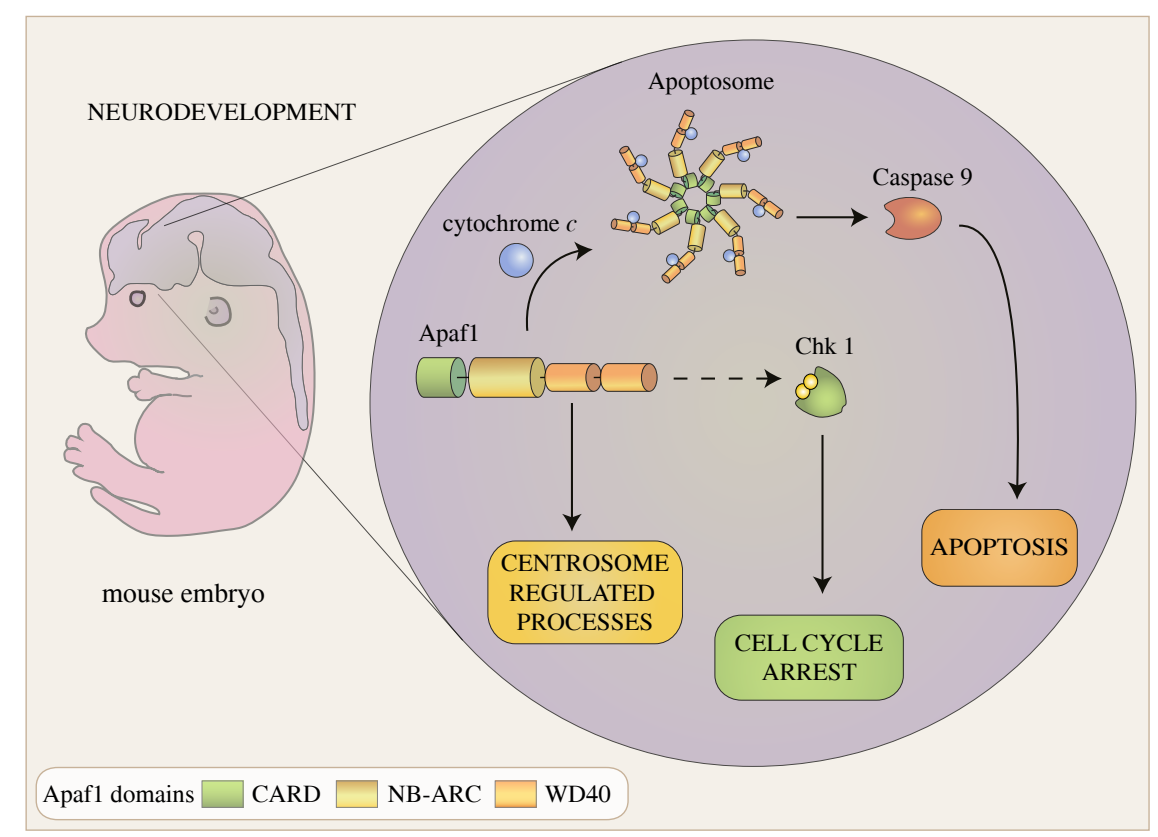




\section{Acknowledgements}

We wish to thank M.W. Bennett, M. Acuña Villa and Laila Fisher for editorial and secretarial work. The Unit of Cell Stress and Survival is supported by grants from the Danish Cancer Society (KBVU R72-A4408 and KBVU R72-A4647); The Bjarne Saxhof Foundation; Lundbeck Foundation (n. R167-2013-16100); and NovoNordisk (n. 7559). Also, we are grateful to AIRC (IG2012); Telethon Foundation (GGP10225); the Italian Ministry of University and Research (PRIN2009 and FIRBAccordidi Programma2011).

\section{References}

BARNES, D.E., STAMP, G., ROSEWELL, I., DENZEL, A. and LINDAHL, T. (1998). Targeted disruption of the gene encoding DNA ligase IV leads to lethality in embryonic mice. Curr Biol 8: 1395-1398.

BARZILAI, A., BITON, S. and SHILOH, Y. (2008). The role of the DNA damage response in neuronal development, organization and maintenance. DNA Repair (Amst) 7: 1010-1027.

BEKKER-JENSEN, S. and MAILAND, N. (2010). Assembly and function of DNAdoublestrand break repair foci in mammalian cells. DNA Repair (Amst) 9: 1219-1228.

BRATTON, S.B. and SALVESEN, G.S. (2010). Regulation of the Apaf-1-caspase-9 apoptosome. J Cell Sci 123: 3209-3214.

CECCONI, F., ALVAREZ-BOLADO, G., MEYER, B.I., ROTH, K.A. and GRUSS, P. (1998). Apaf1 (CED-4 homolog) regulates programmed cell death in mammalian development. Cell 94: 727-737.

CECCONI, F., ROTH, K.A., DOLGOV, O., MUNARRIZ, E., ANOKHIN, K., GRUSS, P. and SALMINEN, M. (2004). Apaf1-dependent programmed cell death is required for inner ear morphogenesis and growth. Development 131: 2125-2135.

CHOUDHRY, Z., RIKANI, A.A., CHOUDHRY, A.M., TARIQ, S., ZAKARIA, F., ASGHAR, M.W., SARFRAZ, M.K., HAIDER, K., SHAFIQ, A.A. and MOBASSARAH, N.J. (2014). Sonic hedgehog signalling pathway: a complex network. Ann Neurosci 21: 28-31.

DE ANDA, F.C., MELETIS, K., GE, X., REI, D. and TSAI, L.H. (2010). Centrosome motility is essential for initial axon formation in the neocortex. J Neurosci 30: 10391-10406.

DE ZIO, D., BORDI, M. and CECCONI, F. (2012). Oxidative DNA damage in neurons: implication of ku in neuronal homeostasis and survival. Int J Cell Bio/2012:752420.

DE ZIO, D., BORDI, M., TINO, E., LANZUOLO, C., FERRARO, E., MORA, E., CICCOSANTI, F., FIMIA, G.M., ORLANDO, V. and CECCONI, F. (2011). The DNA repair complex Ku70/86 modulates Apaf1 expression upon DNA damage. Cell Death Differ 18: 516-527.

DE ZIO, D., GIUNTA, L., CORVARO, M., FERRARO, E. and CECCONI, F. (2005). Expanding roles of programmed cell death in mammalian neurodevelopment. Semin Cell Dev Biol 16: 281-294.

DE ZIO, D., MOLINARI, F., RIZZA, S., GATTA, L., CIOTTI, M.T., SALVATORE, A.M., MATHIASSEN, S.G., CWETSCH, A.W., FILOMENI, G., ROSANO, G. and FERRARO, E. (2015). Apaf1-deficient cortical neurons exhibit defects in axonal outgrowth. Cell Mol Life Sci In press (DOI 10.1007/s00018-015-1927-x)

ELLIS, H.M. and HORVITZ, H.R. (1986). Genetic control of programmed cell death in the nematode C. elegans. Cell 44: 817-829.

ELLIS, R.E. and HORVITZ, H.R. (1991). Two C. elegans genes control the programmed deaths of specific cells in the pharynx. Development 112: 591-603.

ELLIS, R.E., JACOBSON, D.M. and HORVITZ, H.R. (1991). Genes required for the engulfment of cell corpses during programmed cell death in Caenorhabditis elegans. Genetics 129: 79-94

FANT, X., GNADT, N., HAREN, L. and MERDES, A. (2009). Stability of the small gamma-tubulin complex requires HCA66, a protein of the centrosome and the nucleolus. J Cell Sci 122: 1134-1144.

FERRARO, E., PESARESI, M.G., DE ZIO, D., CENCIONI, M.T., GORTAT, A., COZZOLINO, M., BERGHELLA, L., SALVATORE, A.M., OETTINGHAUS, B., SCORRANO, L., PEREZ-PAYA, E. and CECCONI, F. (2011). Apaf1 plays a pro-survival role by regulating centrosome morphology and function. J Cell Sci124:3450-3463.

FRAPPART, P.O., TONG, W.M., DEMUTH, I., RADOVANOVIC, I., HERCEG, Z., AGUZZI, A., DIGWEED, M. and WANG, Z.Q. (2005). An essential function for NBS1 in the prevention of ataxia and cerebellar defects. Nat Med 11: 538-544.

GALLUZZI, L., VITALE, I., ABRAMS, J.M., ALNEMRI, E.S., BAEHRECKE, E.H., BLA-
GOSKLONNY, M.V., DAWSON, T.M., DAWSON, V.L., EL-DEIRY, W.S., FULDA S., GOTTLIEB, E., GREEN, D. R., HENGARTNER, M. O., KEPP, O., KNIGHT, R. A., KUMAR, S., LIPTON, S. A., LU, X., MADEO, F., MALORNI, W., MEHLEN, P., NUNEZ, G., PETER, M. E., PIACENTINI, M., RUBINSZTEIN, D. C., SHI, Y., SIMON, H. U., VANDENABEELE, P., WHITE, E., YUAN, J., ZHIVOTOVSKY, B., MELINO, G. and KROEMER, G. (2012). Molecular definitions of cell death subroutines: recommendations of the Nomenclature Committee on Cell Death 2012. Cell Death Differ 19: 107-120

GAMA, V., SWAHARI, V., SCHAFER, J., KOLE, A.J., EVANS, A., HUANG, Y., CLIFFE, A., GOLITZ, B., SCIAKY, N., PEI, X.H., XIONG, Y. and DESHMUKH, M. (2014). The E3 ligase PARC mediates the degradation of cytosolic cytochrome $c$ to promote survival in neurons and cancer cells. Sci Signal 7: ra67.

GAO, Y., SUN, Y., FRANK, K.M., DIKKES, P., FUJIWARA, Y., SEIDL, K.J., SEKIGUCHI, J.M., RATHBUN, G.A., SWAT, W., WANG, J., BRONSON, R. T., MALYNN, B. A. BRYANS, M., ZHU, C., CHAUDHURI, J., DAVIDSON, L., FERRINI, R., STAMATO, T., ORKIN, S. H., GREENBERG, M. E. and ALT, F. W. (1998). A critical role for DNA end-joining proteins in both lymphogenesis and neurogenesis. Cell 95: 891-902.

GU, Y., SEKIGUCHI, J., GAO, Y., DIKKES, P., FRANK, K., FERGUSON, D., HASTY, P., CHUN, J. and ALT, F.W. (2000). Defective embryonic neurogenesis in Kudeficient but not DNA-dependent protein kinase catalytic subunit-deficient mice. Proc Natl Acad Sci USA 97: 2668-2673.

HAKEM, R., HAKEM, A., DUNCAN, G.S., HENDERSON, J.T., WOO, M., SOENGAS, M.S., ELIA, A., DE LA POMPA, J.L., KAGI, D., KHOO, W., POTTER, J., YOSHIDA, R., KAUFMAN, S. A., LOWE, S. W., PENNINGER, J. M. and MAK, T. W. (1998). Differential requirement for caspase 9 in apoptotic pathways in vivo. Cell 94: 339-352.

HAO, Z., DUNCAN, G.S., CHANG, C.C., ELIA, A., FANG, M., WAKEHAM, A., OKADA, H., CALZASCIA, T., JANG, Y., YOU-TEN, A., YEH, W. C., OHASHI, P., WANG, $X$. and MAK, T. W. (2005). Specific ablation of the apoptotic functions of cytochrome $C$ reveals a differential requirement for cytochrome $C$ and Apaf- 1 in apoptosis. Cell 121: 579-591.

HARRIS, B.S., FRANZ, T., ULLRICH, S., COOK, S., BRONSON, R.T. and DAVISSON, M.T. (1997). Forebrain overgrowth (fog): a new mutation in the mouse affecting neural tube development. Teratology 55: 231-240.

HIGGINBOTHAM, H.R. and GLEESON, J.G. (2007). The centrosome in neuronal development. Trends Neurosci 30: 276-283.

HONARPOUR, N., GILBERT, S.L., LAHN, B.T., WANG, X. and HERZ, J. (2001). Apaf-1 deficiency and neural tube closure defects are found in fog mice. Proc Natl Acad Sci USA 98: 9683-9687.

HORVITZ, H.R. (1999). Genetic control of programmed cell death in the nematode Caenorhabditis elegans. Cancer Res 59: 1701s-1706s.

HOUDE, C., BANKS, K.G., COULOMBE, N., RASPER, D., GRIMM, E., ROY, S. SIMPSON, E.M. and NICHOLSON, D.W. (2004). Caspase-7 expanded function and intrinsic expression level underlies strain-specific brain phenotype of caspase3-null mice. J Neurosci 24: 9977-9984.

KHODJAKOV, A. and RIEDER, C.L. (1999). The sudden recruitment of gamma-tubulin to the centrosome at the onset of mitosis and its dynamic exchange throughout the cell cycle, do not require microtubules. J Cell Biol 146: 585-596.

KOLE, A.J., SWAHARI, V., HAMMOND, S.M. and DESHMUKH, M. (2011). miR-29b is activated during neuronal maturation and targets $\mathrm{BH} 3-$ only genes to restrict apoptosis. Genes Dev 25: 125-130.

KUAN, C.Y., ROTH, K.A., FLAVELL, R.A. and RAKIC, P. (2000). Mechanisms of programmed cell death in the developing brain. Trends Neurosci 23: 291-297.

KUIDA, K., HAYDAR, T.F., KUAN, C.Y., GU, Y., TAYA, C., KARASUYAMA, H., SU, M.S., RAKIC, P. and FLAVELL, R.A. (1998). Reduced apoptosis and cytochrome c-mediated caspase activation in mice lacking caspase 9. Cell 94: 325-337.

KUIDA, K., ZHENG, T.S., NA, S., KUAN, C., YANG, D., KARASUYAMA, H., RAKIC P. and FLAVELL, R.A. (1996). Decreased apoptosis in the brain and premature lethality in CPP32-deficient mice. Nature 384: 368-372.

KUIJPERS, M. and HOOGENRAAD, C.C. (2011). Centrosomes, microtubules and neuronal development. Mol Cell Neurosci 48: 349-358.

LEVEILLE, F., PAPADIA, S., FRICKER, M., BELL, K.F., SORIANO, F.X., MARTEL, M.A., PUDDIFOOT, C., HABEL, M., WYLLIE, D.J., IKONOMIDOU, C., TOLKOVSKY, A.M. and HARDINGHAM, G.E. (2010). Suppression of the intrinsic apoptosis pathway by synaptic activity. $J$ Neurosci 30: 2623-2635.

LONG, A.B., KAISER, W.J., MOCARSKI, E.S. and CASPARY, T. (2013). Apaf1 apoptotic function critically limits Sonic hedgehog signaling during craniofacial 
development. Cell Death Differ 20: 1510-1520.

MASSA, V., SAVERY, D., YBOT-GONZALEZ, P., FERRARO, E., RONGVAUX, A., CECCONI, F., FLAVELL, R., GREENE, N.D. and COPP, A.J. (2009). Apoptosis is not required for mammalian neural tube closure. Proc Natl Acad Sci USA 106: 8233-8238.

MATISE, M.P. and WANG, H. (2011). Sonic hedgehog signaling in the developing CNS where it has been and where it is going. Curr Top Dev Biol 97: 75-117.

METZSTEIN, M.M., STANFIELD, G.M. and HORVITZ, H.R. (1998). Genetics of programmed cell death in C. elegans: past, present and future. Trends Genet 14: 410-416.

MORENO, S., FERRARO, E., ECKERT, S. and CECCONI, F. (2002). Apaf1 reduced expression levels generate a mutant phenotype in adult brain and skeleton. Cell Death Differ 9: 340-342.

MOUHAMAD, S., GALLUZZI, L., ZERMATI, Y., CASTEDO, M. and KROEMER, G. (2007). Apaf-1 Deficiency Causes Chromosomal Instability. Cell Cycle6:3103-3107.

NONOMURA, K., YAMAGUCHI, Y., HAMACHI, M., KOIKE, M., UCHIYAMA, Y., NAKAZATO, K., MOCHIZUKI, A., SAKAUE-SAWANO, A., MIYAWAKI, A., YOSHIDA, H., KUIDA, K. and MIURA, M. (2013). Local apoptosis modulates early mammalian brain development through the elimination of morphogen-producing cells. Dev Cell 27: 621-634.

O'DRISCOLL, M. and JEGGO, P.A. (2008). The role of the DNA damage response pathways in brain development and microcephaly: insight from human disorders. DNA Repair (Amst) 7: 1039-1050.

OEGEMA, K., WIESE, C., MARTIN, O.C., MILLIGAN, R.A., IWAMATSU, A., MITCHISON, T.J. and ZHENG, Y. (1999). Characterization of two related Drosophila gamma-tubulin complexes that differ in their ability to nucleate microtubules. $J$ Cell Biol 144: 721-733.

OHSAWA, S., HAMADA, S., KUIDA, K., YOSHIDA, H., IGAKI, T. and MIURA, M. (2010). Maturation of the olfactory sensory neurons by Apaf-1/caspase-9-mediated caspase activity. Proc Natl Acad Sci USA 107: 13366-13371.

OPPENHEIM, R.W., BLOMGREN, K., ETHELL, D.W., KOIKE, M., KOMATSU, M., PREVETTE, D., ROTH, K.A., UCHIYAMA, Y., VINSANT, S. and ZHU, C. (2008). Developing postmitotic mammalian neurons in vivo lacking Apaf-1 undergo programmed cell death by a caspase-independent, nonapoptotic pathway involving autophagy. J Neurosci 28: 1490-1497.

ORII, K.E., LEE, Y., KONDO, N. and MCKINNON, P.J. (2006). Selective utilization of nonhomologous end-joining and homologous recombination DNA repair pathways during nervous system development. Proc Natl Acad Sci USA 103: 10017-10022.

WRIGHT, K.M., SMITH, M.I., FARRAG, L. and DESHMUKH, M. (2007). Chromatin modification of Apaf-1 restricts the apoptotic pathway in mature neurons. $J$ Cell Biol 179: 825-832.

YAN, N., CHAI, J., LEE, E.S., GU, L., LIU, Q., HE, J., WU, J.W., KOKEL, D., LI, H., HAO, Q., XUE, D. and SHI, Y. (2005). Structure of the CED-4-CED-9 complex provides insights into programmed cell death in Caenorhabditis elegans. Nature 437: 831-837.

YOSHIDA, H., KONG, Y.Y., YOSHIDA, R., ELIA, A.J., HAKEM, A., HAKEM, R. PENNINGER, J.M. and MAK, T.W. (1998). Apaf1 is required for mitochondrial pathways of apoptosis and brain development. Cell 94: 739-750.

YUAN, S. and AKEY, C.W. (2013). Apoptosome structure, assembly, and procaspase activation. Structure 21: 501-515.

YUAN, S., TOPF, M., REUBOLD, T.F., ESCHENBURG, S. and AKEY, C.W. (2013). Changes in Apaf-1 conformation that drive apoptosome assembly. Biochemistry 52: 2319-2327.

ZERMATI, Y., MOUHAMAD, S., STERGIOU, L., BESSE, B., GALLUZZI, L., BOEHRER, S., PAULEAU, A.L., ROSSELLI, F., D'AMELIO, M., AMENDOLA, R., CASTEDO, M., HENGARTNER, M., SORIA, J. C., CECCONI, F. and KROEMER, G. (2007). Nonapoptotic role for Apaf-1 in the DNA damage checkpoint. Mol Cell28: 624-637. 


\section{Further Related Reading, published previously in the Int. J. Dev. Biol.}

Revisiting DNA damage repair, p53-mediated apoptosis and cisplatin sensitivity in germ cell tumors

Francesca Cavallo, Darren R. Feldman and Marco Barchi

Int. J. Dev. Biol. (2013) 57: 273-280

Regulation of programmed cell death during neural induction in the chick embryo Anna Gibson, Neil Robinson, Andrea Streit, Guojun Sheng and Claudio D. Stern Int. J. Dev. Biol. (2011) 55: 33-43

Life-giving caspases: revealing new roles during mouse embryo preimplantation development

Dolores Busso, Calixto Dominguez, Tomas Perez-Acle and Ricardo D. Moreno Int. J. Dev. Biol. (2010) 54: 857-865

Apoptosis in Drosophila: compensatory proliferation and undead cells Francisco A. Martín, Ainhoa Peréz-Garijo and Ginés Morata Int. J. Dev. Biol. (2009) 53: 1341-1347

Key apoptosis regulating proteins are down-regulated during postnatal tissue development

Shane D. Madden, Maryanne Donovan and Thomas G. Cotter Int. J. Dev. Biol. (2007) 51: 415-424

5 yr ISI Impact Factor $(2013)=2.879$
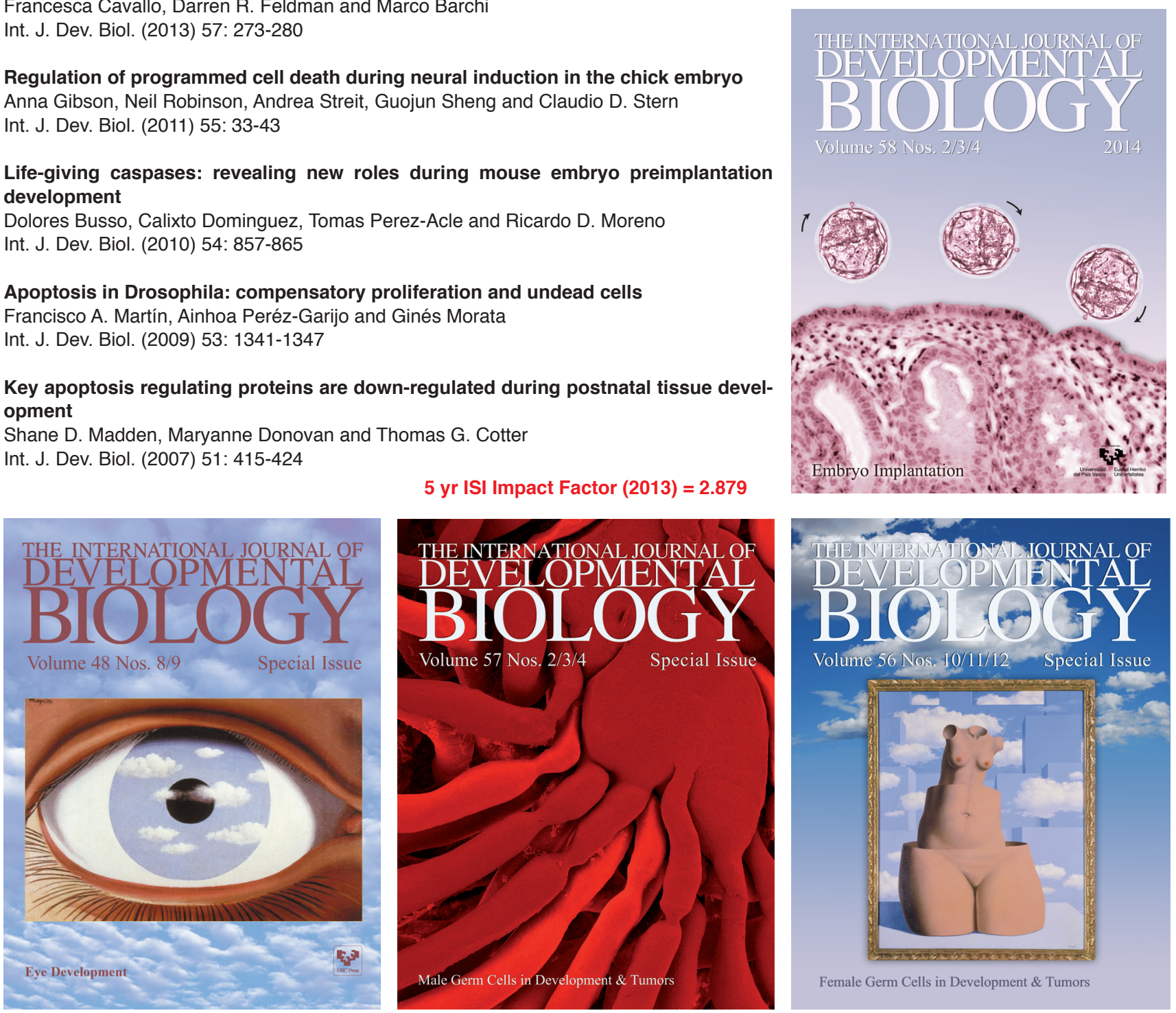

Volume 56 Nos. 10/11/12 - Special Issue

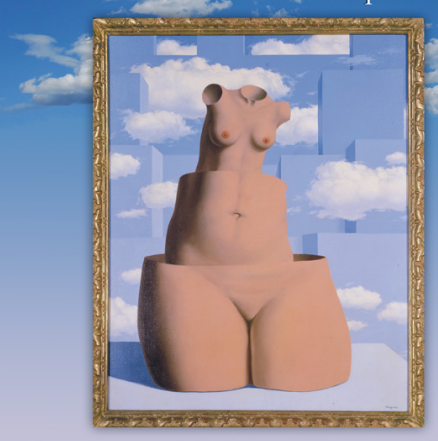

Female Germ Cells in Development \& Tumors 